\title{
Silica earth provoked lung fibrosis with stimulation of lysosomal enzymes and lipid peroxidation in rats
}

\author{
JOLANTA JAJTE,' IWONA LAO, ' JUSTYNA M WIŚNIEWSKA-KNYPL, ${ }^{1}$ \\ TERESA WROŃSKA-NOFER,' \\ From the Departments of Biochemistry ${ }^{1}$ and Pathomorphology, ${ }^{2}$ Professor J Nofer Institute of Occupational \\ Medicine, 90-950 Lodz, Poland
}

\begin{abstract}
The dynamics of the biological response of pulmonary tissue to silica dust (silica earth from Piotrowice, Poland, recommended as a domestic reference fibrogenic standard) was studied in rats after single-shot intratracheal instillation of a suspension of $20 \mathrm{mg}$ of the dust for one, three, and seven months. Silica dust provoked pronounced pulmonary fibrosis as inferred from increased collagen content together with pathomorphological alteration (silicotic nodules). The lung burden of silica dust affected the lysosomal subfraction as manifested by an increase in its protein content with concomitant stimulation (release and presumably induction) of $\beta$-glucuronidase and cathepsin $D$ and a transient (up to three months) stimulation of lipid peroxidation. Stimulation of activity of lysosomal enzymes and lipid peroxidation mediated by silica dust may reflect destructive metabolic processes resulting in the development of pulmonary fibrosis as the sign of a pathological repair mechanism. The extent of the effects brought about by silica earth testify that it may be recommended as a reference standard for evaluating the potential health hazard from industrial exposure to dusts containing $\mathrm{SiO}_{2}$.
\end{abstract}

Occupational exposure to dust containing $\mathrm{SiO}_{2}$ may lead to the development of silicosis. ${ }^{.}$The interaction of the dust particles with macrophages (paralleled by phagocytosis) has been postulated to be the critical factor in the action of silica on pulmonary tissues. This results in release of the macrophage fibrogenic factor stimulating fibroblasts to the overproduction of collagen and thus initiating a fibrotic process. ${ }^{2}$

On the other hand, the sequence of events in the process of phagocytosis of silica dust by macrophages involves the formation of secondary lysosomes (phagolysomes) and the chemical interaction of $\mathrm{SiO}_{2}$ with lysosomal membranes leading directly to rupture of the membranes, release of their hydrolytic enzymes, and, finally, cell death..$^{3-5}$

In vitro experiments with cultures of alveolar macrophages and isolated red blood cells testing the release of the hydrolytic cytoplasmic and lysosomal enzymes into cellular medium allows one to assume that the interaction of $\mathrm{SiO}_{2}$ with phagolysosomal membranes plays a crucial part in the $\mathrm{SiO}_{2}$ provoked detrimental processes in the lungs. ${ }^{67}$

It is also possible, however, that destabilisation of the membrane through the interaction with $\mathrm{SiO}_{2}$ may

Accepted 2 March 1987 contribute to the concomitant enhancement of lipid peroxidation as may be inferred from direct in vitro assays with red blood cells and macrophages ${ }^{8-11}$ and in vivo tests on rats with a short term lung burden of silica DQ-12. ${ }^{12}$

Thus both phenomena, lysosomal enzymes release, and lipid peroxidation enhancement may influence propagation of destructive processes in the membrane in the lung.

The present investigation was undertaken to determine whether in vivo, long lasting pulmonary deposition of silica dust (silica earth from Piotrowice, Poland, recommended as a domestic reference fibrogenic standard) affects lysosomal enzyme activity and the lipid peroxidation rate as compared with the fibrotic response of the lungs. Study of the dynamics and extent of these changes may be useful for the comparative estimation of the potential biological aggressiveness of $\mathrm{SiO}_{2}$ containing dusts and contribute to the elucidation of the underlying mechanism of its harmful effects.

\section{Materials and methods}

ANIMALS AND TREATMENT

Experiments were carried out on male $200-250 \mathrm{~g}$

Wistar rats fed a laboratory food, Murigran 
(Bioveterinary Industries, Gorzów Wlkp, Poland) with tap water ad libitum.

The rats were exposed by intratracheal instillation to silica earth from Piotrowice in Poland $(78.6 \%$ of $\mathrm{SiO}_{2}$, av $96 \%$ of respirable fraction ${ }^{13}$ ) recommended as a domestic reference fibrogenic standard for $\mathrm{SiO}_{2}$ containing industrial dusts. ${ }^{14}$ Controls were exposed in a similar manner either to rutile $\left(\mathrm{TiO}_{2}\right.$ crystal lattice), an inert respirable dust, ${ }^{136}$ or to physiological saline.

A suspension of $20 \mathrm{mg}$ of the appropriate dust in $0.3 \mathrm{ml}$ saline or $0.3 \mathrm{ml}$ saline only was sprinkled, under anaesthesia with a drop of $4 \%$ ksylocain, directly on to the glottis. The animals were killed at one, three, and seven months after dosing and their lungs were used for further tests.

\section{BIOCHEMICAL ASSAYS}

The rats were beheaded under a light ether anaesthesia and the lungs were excised, washed with physiological saline, blotted on a filter paper, and immediately processed. The lungs were weighed directly and the dry weight was determined after initial five hour desiccation at $50^{\circ} \mathrm{C}$ and then, to a constant weight, over phosphorus pentoxide.

Hydroxyproline in the collagen fraction of dry lungs was determined colorimetrically after extraction procedure at $550 \mathrm{~nm}^{17}$ and converted to collagen by using the factor $7 \cdot 46 .{ }^{18}$

The lysosomal fraction was extracted using the method of Sawant et al. ${ }^{19}$ A $10 \%(\mathrm{w} / \mathrm{v})$ homogenate of fresh lungs in $0.25 \mathrm{M}$ sucrose $-0.01 \mathrm{M}$ Tris- $\mathrm{HCl}, \mathrm{pH}$ 7.4 obtained with Teflon glass Potter-Elvehjem homogeniser and squeezed through a bolting cloth (pores of $200 \mu \mathrm{m}$ in diameter), was successively centrifuged at $4^{\circ} \mathrm{C}$ at $900 \mathrm{~g}$ for 10 minutes, $7000 \mathrm{~g}$ for 15 minutes, and $20400 \mathrm{~g}$ for 35 minutes to sediment the nuclei, mitochondria, and lysosomes, respectively. After washing with $1 \cdot 15 \% \mathrm{KCl}$ and recentrifugation at $20400 \mathrm{~g}$ for 35 minutes, the lysosomal fraction was suspended by rehomogenisation in $1.15 \% \mathrm{KCl}$. The protein content was determined according to Lowry et al. $^{20}$

Activity of $\beta$-glucuronidase (EC 3.2.1.31) was assayed with p-nitrophenol glucuronide as substrate; the p-nitrophenol formed was determined colorimetrically at $400 \mathrm{~nm} .^{21}$

Activity of cathepsin D (EC 3.4.23.5) was assayed with denaturated haemoglobin as substrate ${ }^{22}$; the acid soluble products of hydrolysis of the protein was determined with Folin phenol reagent. ${ }^{20}$

Lipid peroxidation in the homogenates and lysosomal membranes was evaluated on the basis of the detection of thiobarbituric acid reactive substances. ${ }^{23}$ An extinction coefficient of $156000 \mathrm{M}^{-1} / \mathrm{cm}^{19}$ was used for quantifying malondialdehyde. ${ }^{24}$
The results were statistically evaluated using Student's $t$ test.

\section{PATHOMOR PHOLOGICAL EXAMINATION OF THE LUNGS}

The lungs were fixed in situ at full inflation by the infusion of $10 \%$ neutral buffered formalin through the larynx and trachea. After ligation of the trachea all the thoracic organs were excised and placed in $10 \%$ buffered formalin solution for continued fixation. The sections were then gradually dehydrated in isopropanol (50-96\%), cleared in xylene, and impregnated with paraffin. Haematoxylin and eosin stained paraffin sections were examined with a light microscope.

\section{Results}

The biological response of the rat's pulmonary tissue to a silica earth dust burden lasting for seven months is presented in table 1 . One month after intratracheal instillation both the fresh and dry weights of the lungs had increased twofold and continued for the next six months. This change resulted from the development of pulmonary fibrosis since the collagen content of the lungs increased simultaneously. The lysosomal protein content, an index of the phagolysosmal response in silica laden cells (macrophages) increased concurrently.

These observations were confirmed by pathomorphological examination of the lungs during the course of exposure to silica earth dust (figs 1-5). Figure 1 shows a fragment of lung tissue of a control, saline treated rat with a normal pulmonary parenchyma and normal alveoli and bronchi. In fig 2 a fragment of lung tissue from a rat treated with rutile is shown: black dots represent rutile particles deposited in the walls of the alveolar ducts and in the cytoplasm of phagocytes in the lumen of the alveoli. No signs of progressive, reactive changes were observed. In the lungs from rats exposed to silica numerous silicotic nodules with strands of fibrous connective tissue were seen (fig 3) and as the exposure was continued, cytolysis of alveolar macrophages with thickening of alveolar septa in the periphery of nodules occurred (fig 4). At the end of seven months exposure pronounced fibrosis developed, resulting in the reduction of the pulmonary air spaces, glazing of the connective tissue, and focal cell disintegration. Thus the silica penetrating deeply into the lung had exerted a deleterious fibrogenic effect at its target sites.

The biochemical findings in the lysosomal subfraction of the pulmonary cells of rats exposed to silica, compared with the controls, also showed the damaging effects of the dust on the cell membrane as deduced from the increase (release) in the activity of the 
Table 1 Increase in lung weight and pulmonary content of collagen and lysosomal proteins in rats after intratracheal instillation of silica earth

\begin{tabular}{|c|c|c|c|c|c|c|}
\hline \multirow[b]{2}{*}{ Treatment } & \multirow{2}{*}{$\begin{array}{l}\text { Period of } \\
\text { exposure } \\
\text { (months) }\end{array}$} & \multirow{2}{*}{$\begin{array}{l}\text { Body weight } \\
\text { (g) }\end{array}$} & \multicolumn{2}{|l|}{ Lungs } & \multirow{2}{*}{$\begin{array}{l}\text { Collagen * } \\
\text { (mg per lungs } \\
\text { dry weight) }\end{array}$} & \multirow{2}{*}{$\begin{array}{l}\text { Lysosomal proteins } \dagger \\
\text { (mg per lungs } \\
\text { fresh weight) }\end{array}$} \\
\hline & & & Fresh weight $(\mathrm{g})$ & Dry weight $(\mathrm{g})$ & & \\
\hline $\begin{array}{l}\text { Saline } \\
\text { Rutile } \\
\text { Silica earth }\end{array}$ & 1 & 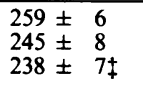 & $\begin{array}{l}1.52 \pm 0.05 \\
1.58 \pm 0.07 \\
3 \cdot 16 \pm 0.20 \$\end{array}$ & $\begin{array}{l}0.26 \pm 0.02 \\
0.24 \pm 0.01 \\
0.55 \pm 0.05 \S\end{array}$ & $\begin{array}{l}28.87 \pm 1.30 \\
30 \cdot 29 \pm 1.47 \\
69.75 \pm 7.62 \S\end{array}$ & $\begin{array}{c}6.23 \pm 0.30 \\
6.48 \pm 0.63 \\
13.90 \pm 0.95 \S\end{array}$ \\
\hline $\begin{array}{l}\text { Saline } \\
\text { Rutile } \\
\text { Silica earth }\end{array}$ & 3 & $\begin{array}{l}324 \pm 9 \\
330 \pm 9 \\
267 \pm 11 \S\end{array}$ & $\begin{array}{l}1.88 \pm 0.18 \\
1.75 \pm 0.08 \\
4.02 \pm 0.33 \S\end{array}$ & $\begin{array}{l}0.26 \pm 0.02 \\
0.35 \pm 0.03 \\
0.68 \pm 0.08 \S\end{array}$ & $\begin{array}{l}30.81 \pm 2.27 \\
42.60 \pm 1.98 \ddagger \\
97.43 \pm 10 \cdot 15 \$\end{array}$ & $\begin{array}{c}8.08 \pm 0.38 \\
8.05 \pm 0.35 \\
17.69 \pm 0.80 \S\end{array}$ \\
\hline $\begin{array}{l}\text { Saline } \\
\text { Rutile } \\
\text { Silica earth }\end{array}$ & 7 & $\begin{array}{l}351 \pm 13 \\
383 \pm 15 \\
343 \pm 13\end{array}$ & $\begin{array}{l}1.97 \pm 0.08 \\
2.14 \pm 0.08 \\
3.82 \pm 0.19 \S\end{array}$ & $\begin{array}{l}0.32 \pm 0.01 \\
0.32 \pm 0.02 \\
0.58 \pm 0.05 \S\end{array}$ & $\begin{array}{ll}38.64 \pm & 1 \cdot 75 \\
41.78 \pm & 2.68 \\
79.60 \pm & 6.86 \S\end{array}$ & $\begin{aligned} 8 \cdot 27 & \pm 0.39 \\
10.91 & \pm 0.86 \| \\
18.34 & \pm 0.76 \$\end{aligned}$ \\
\hline
\end{tabular}

The rats were dosed intratracheally with (1) $20 \mathrm{mg}$ of silica earth in $0 \cdot 3 \mathrm{ml}$ of saline and (2) reference controls with $20 \mathrm{mg}$ rutile (TiO crystal lattice) suspended in $0.3 \mathrm{ml}$ saline or $0.3 \mathrm{ml}$ saline only.

Results are the means \pm SE for at least 12 rats.

*Hydroxyproline was converted to collagen by using a factor $7 \cdot 46{ }^{18}$

†Determined according to Lowry et al. ${ }^{20}$

$\| \ddagger$ §significantly different from concurrent control at $\mathrm{p}<0.05,0.01$, and 0.001 .

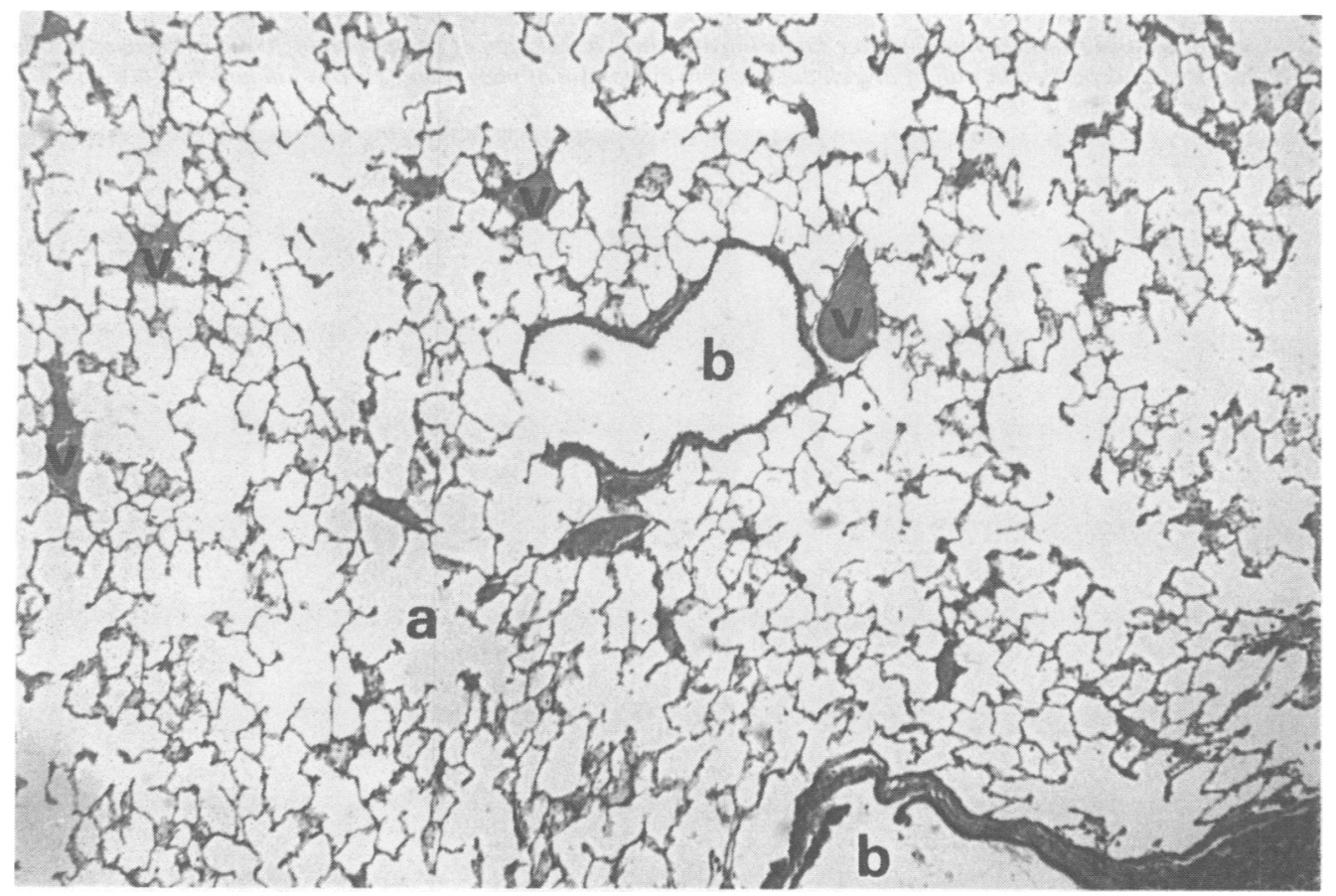

Fig 1 Lung of control rat, three months after intratracheal instillation of $0.3 \mathrm{ml}$ physiological saline. Normal structure of pulmonary parenchyma with regular air space of alveoli $(a)$, smooth contour of bronchi $(b)$, and blood vessels (v) are seen. (Haematoxylin and eosin $\times 95$.) 


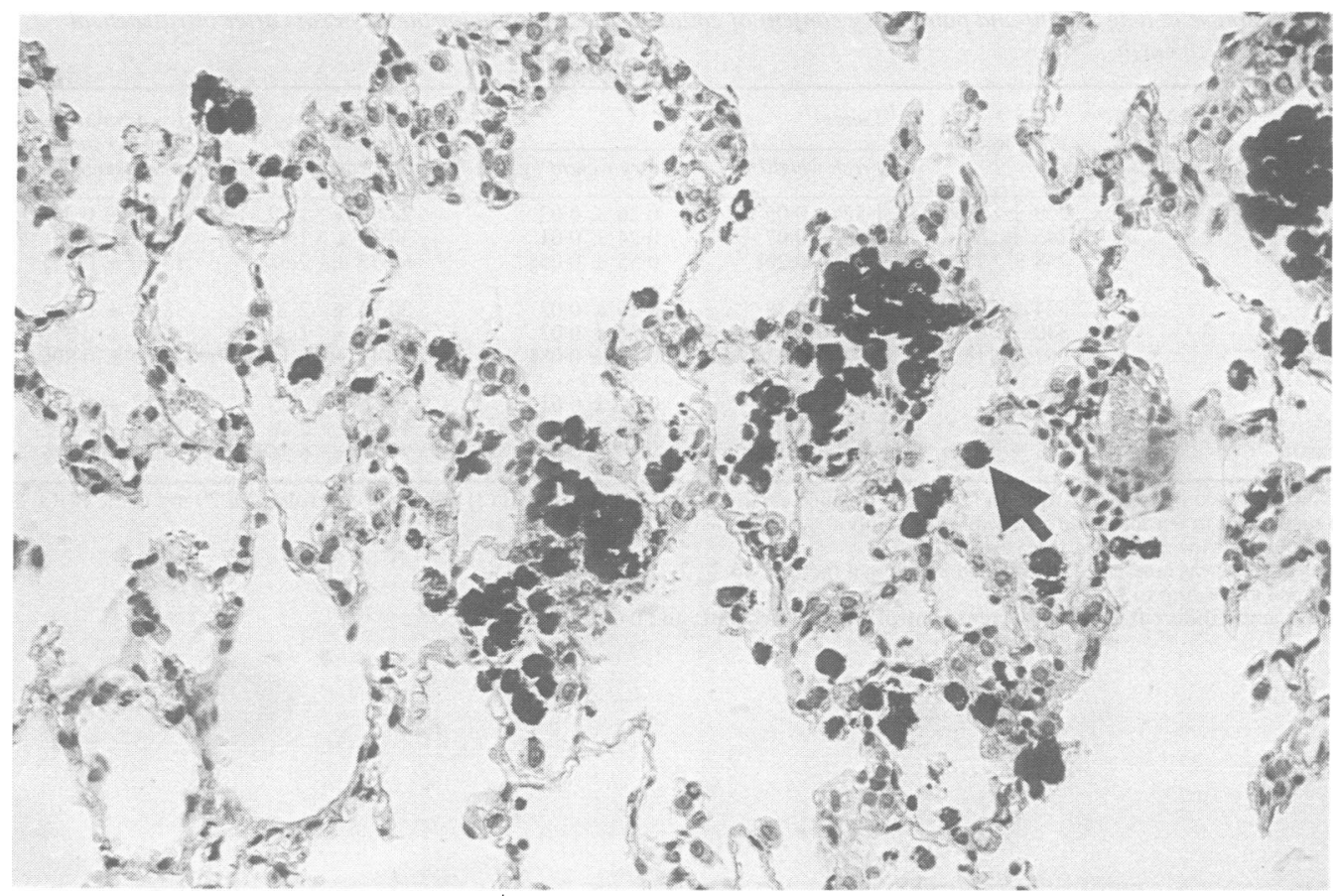

Fig 2 Lung of control rat three months after single intratracheal instillation of suspension of $20 \mathrm{mg}$ rutile dust. Rutile (deep black) is seen deposited in wall of alveoli ducts and in cytoplasm of phagocytes (arrow) in lumen of alveoli. (Haematoxylin and eosin $\times$ 95.)

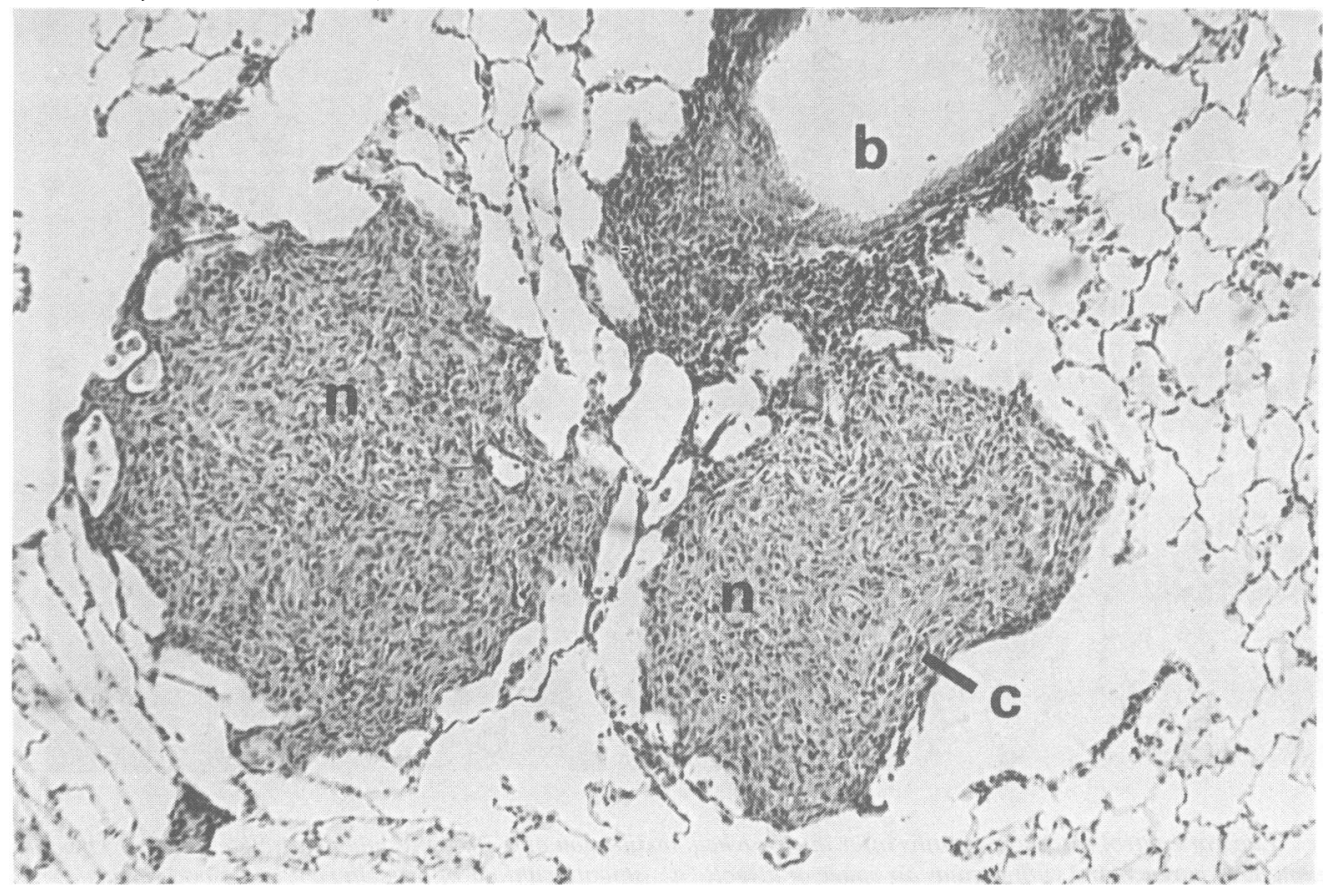

Fig 3 Lung of rat three months after intratracheal instillation of suspension of 20 mg silica earth dust. In vicinity of bronchi (b) two silicotic nodules ( $n$ ) with strands of fibrous connective tissue (c) are seen. (Haematoxylin and eosin $\times$ 95.) 


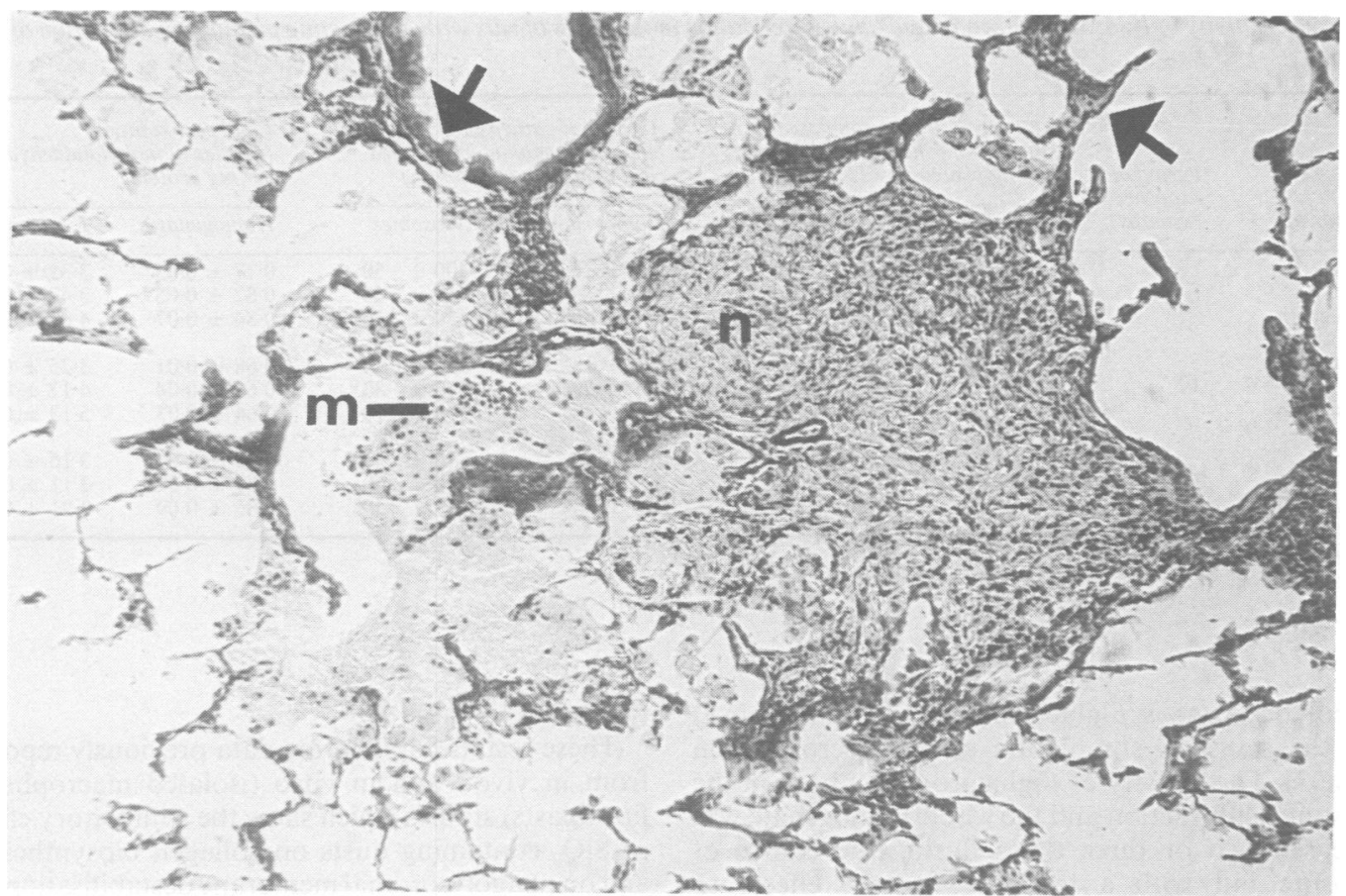

Fig 4 Lung of rat three months after intratracheal instillation of $20 \mathrm{mg}$ silica earth dust. In vicinity of silicotic nodule (n) cytolysis of alveolar macrophages $(m)$ is seen. Note thickening of alveolar septa in periphery of nodule (arrows).

(Haematoxylin and eosin $\times$ 95.)

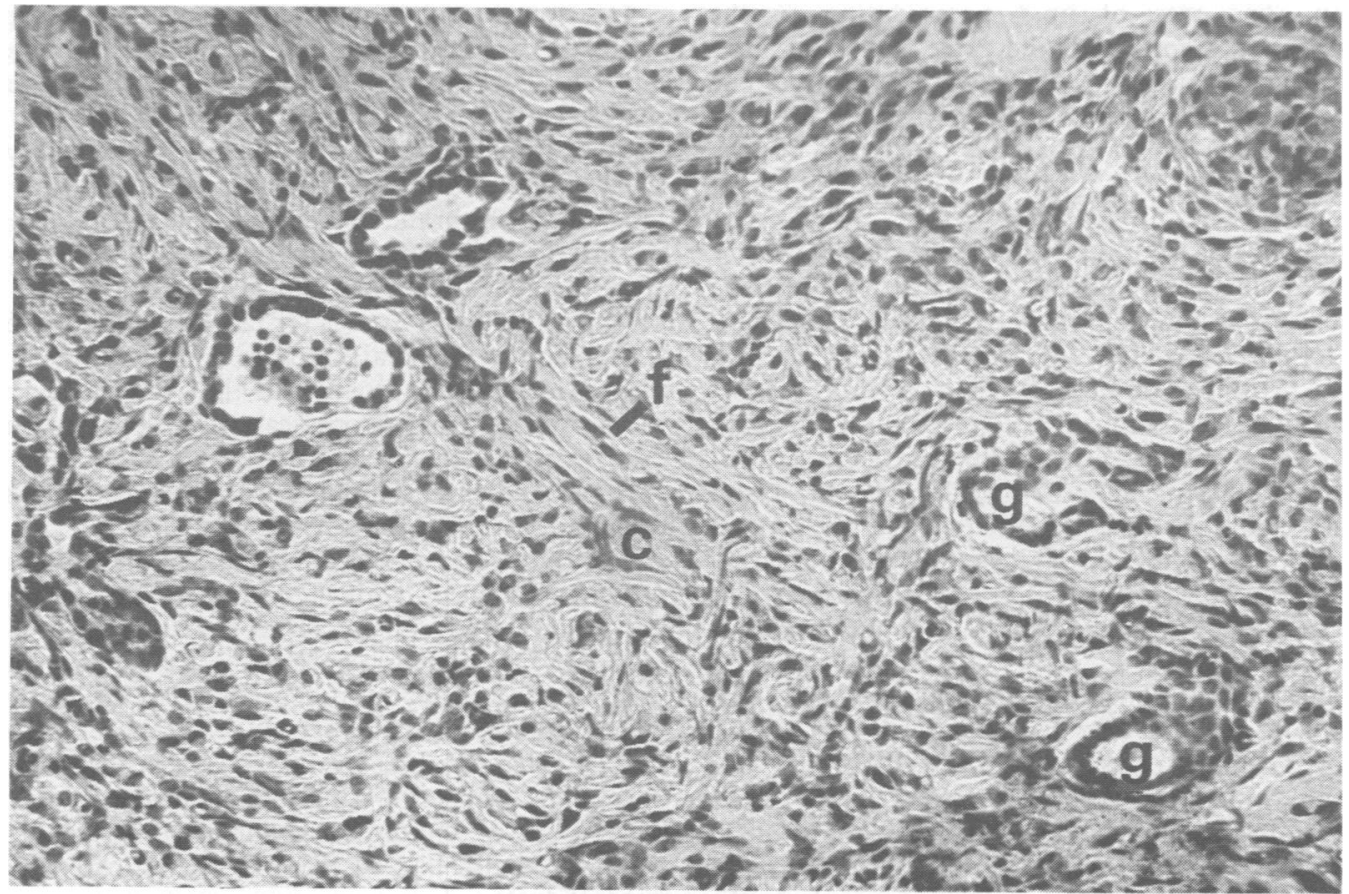

Fig 5 Lung of rat seven months after intratracheal instillation of silica earth. Fragment of silicotic nodule with numerous fibroblasts $(f)$ surrounded by bundles of collagen $(c)$ and some multinuclear giant cells $(g)$.

(Haematoxylin and eosin $\times 240$.) 
Table 2 Activity of lysosomal enzymes and lipid peroxidation in the lungs of rats with long lasting pulmonary deposition of silica earth

\begin{tabular}{|c|c|c|c|c|c|c|c|}
\hline Treatment & $\begin{array}{l}\text { Period of } \\
\text { exposure } \\
\text { (months) }\end{array}$ & \multicolumn{2}{|c|}{$\begin{array}{l}\text { Activity of } \beta \text {-glucuronidase } \\
\text { (nmoles of p-nitrophenol formed } \\
\text { per } \mathrm{mg} \text { protein per } 15 \text { min) }\end{array}$} & \multicolumn{2}{|c|}{$\begin{array}{l}\text { Activity of cathepsin } D \\
\text { ( } \mu \text { g of hemoglobin hydrolysed } \\
\text { per mg protein per } 15 \text { min) }\end{array}$} & \multicolumn{2}{|c|}{$\begin{array}{l}\text { Lipid peroxidation } \\
\text { (nmoles of malondialdehyde } \\
\text { per } m \text { g protein) }\end{array}$} \\
\hline $\begin{array}{l}\text { Saline } \\
\text { Rutile } \\
\text { Silica earth }\end{array}$ & 1 & $\begin{array}{r}52 \pm 5 \\
81 \pm 7 \ddagger \\
265 \pm 30 \$\end{array}$ & $\begin{aligned} 60 & \pm 10 \\
70 & \pm 20 \\
230 & \pm 30 \S\end{aligned}$ & $\begin{array}{l}273 \pm 26 \\
310 \pm 24 \\
625 \pm 60 \$\end{array}$ & $\begin{array}{l}400 \pm 50 \\
450 \pm 50 \\
630 \pm 40 \ddagger\end{array}$ & $\begin{array}{l}0.77 \pm 0.05 \\
0.82 \pm 0.05 \\
0.84 \pm 0.07\end{array}$ & $\begin{array}{l}3.35 \pm 0.40 \\
3.47 \pm 0.52 \\
4.03 \pm 0.58\end{array}$ \\
\hline $\begin{array}{l}\text { Saline } \\
\text { Rutile } \\
\text { Silica earth }\end{array}$ & 3 & $\begin{aligned} 68 & \pm 3 \\
61 & \pm 5 \\
215 & \pm 19 \S\end{aligned}$ & $\begin{aligned} 70 & \pm 10 \\
70 & \pm 10 \\
160 & \pm 20 \S\end{aligned}$ & $\begin{array}{l}261 \pm 18 \\
271 \pm 29 \\
484 \pm 38 \S\end{array}$ & $\begin{array}{r}510 \pm 90 \\
470 \pm 30 \\
1000 \pm 110 \ddagger\end{array}$ & $\begin{array}{l}0.68 \pm 0.01 \\
0.65 \pm 0.04 \\
0.64 \pm 0.03\end{array}$ & $\begin{array}{l}3 \cdot 25 \pm 0 \cdot 24 \\
4 \cdot 12 \pm 0.38 \\
5 \cdot 13 \pm 0.24\end{array}$ \\
\hline $\begin{array}{l}\text { Saline } \\
\text { Rutile } \\
\text { Silica earth }\end{array}$ & 7 & $\begin{array}{c}66 \pm 12 \\
70 \pm 5 \\
141 \pm 12 \S\end{array}$ & $\begin{array}{c}70 \pm 10 \\
70 \pm 10 \\
140 \pm 10 \ddagger\end{array}$ & $\begin{array}{l}279 \pm 16 \\
279 \pm 17 \\
580 \pm 638\end{array}$ & $\begin{array}{r}340 \pm 40 \\
350 \pm 60 \\
1130 \pm 130 \$\end{array}$ & $\begin{array}{l}0.63 \pm 0.07 \\
0.77 \pm 0.09 \\
0.85 \pm 0.09\end{array}$ & $\begin{array}{l}3.16 \pm 0.30 \\
3.11 \pm 0.27 \\
3.91 \pm 0.36\end{array}$ \\
\hline
\end{tabular}

$\| \ddagger \S$ Details as in table 1.

hydrolytic enzymes, $\beta$-glucuronidase, and cathepsin D and the transient stimulation of lipid peroxidation (table 2). The activity of $\beta$-glucuronidase both in the lysosomal subfraction and the whole homogenate was increased two or three times during the course of exposure but with a tendency for the effects to diminish with time. The activity of cathepsin D increased gradually during the seven months of exposure and was most pronounced in the lysosomal fraction. The rate of lipid peroxidation in the lysosomes was significantly increased only after three months of exposure, although it tended to exceed the initial value during the whole period of observation.

\section{Discussion}

The study has shown that silica earth from Piotrowice ledge (Poland) recommended as a reference domestic standard for testing the fibrogenic effects of mineral dusts (cf Więcek et $a l^{14}$ and Szendzikowski et $a l^{15}$ ) exerts a profound pulmonary effect in rats after its instillation by the trachea in a dose of $20 \mathrm{mg}$ for seven months. The effects include the development of fibrosis with specific silicotic nodules (cf table 1 and figs 1-5) and is accompanied by a lysosomal (phagolysosomal) membrane response manifested by an enhancement of the activity of hydrolytic enzymes and a transient stimulation of lipid peroxidation (cf tables 1 and 2).

It may be postulated that the stimulation of the activity of lysosomal enzymes may be caused by two mechanisms: (1) release of the enzymes from the destabilised membranes due to a direct action of the silica $^{4-6}$ or due to silica provoked lipid peroxidation ${ }^{1125}$; (2) induction of the synthesis of the enzymes as indicated by the increased protein content in the lysosomes (cf table 1).

These results corroborate data previously reported from in vivo ${ }^{26}$ and in vitro (isolated macrophages, fibroblasts) studies which show the stimulatory effects of $\mathrm{SiO}_{2}$ containing dusts on collagen biosynthesis ${ }^{727}$ and on phagolysosomal membrane destabilisation due to changes of the architecture and fluidity of the membrane leading finally to the release of hydrolytic enzymes into the surrounding medium. ${ }^{3628}$

Lysosomes, including phagolysosomes, participate in the physiological turnover of cellular components and the scavenging of undegradable extraneous materials; the first function may be disturbed by absorbed mineral dusts ${ }^{16729}$ and that is the case with silica earth. Among the enzymes released from the lysosomal membranes by silica, cathepsin $\mathrm{D}$ seems to disturb the turnover of cellular proteins predominantly by the hydrolysis of the intracellular proteins ${ }^{356}$ as compared with lysosomes (cf table 1), procollagen ${ }^{30}$ and glycoproteins, matrices for connective tissue. ${ }^{31}$ It seems that the disturbance in the relation between these degradation processes triggers a rebound "repair" mechanism through the formation of collagen and the accumulation of connective tissue, thus leading to fibrosis.

The dynamics of the development of silica earth provoked fibrosis, with signs of specific lysosomal membrane derangements, shows that the "single shot" model of exposure is a valid one for the experimental, in vivo, evaluation of potential biological activity. Since the biological aggressiveness of the silica earth studied extends to the level of the lysosomal subfraction of the lung cells, it may be advisable to recommend it as a reference standard in evaluating the potential health hazard from industrial exposure to mineral dusts. 
This study was carried out under Program of Evaluation of Biological Effects and Occupational Exposure to Industrial Dusts, CI.01.U.02.07 for Central Institute of Labour Protection in Warsaw.

We thank Dr H Woźniak and Dr E Więcek of the Department of Aerosols of the Institute for kindly supplying the silica earth, Mrs H Platak for skilled technical help, and Mrs Z Rudnicka for expert typing.

\section{References}

1 Heppleston AG. Pulmonary toxicology of silica, coal and asbestos. Environ Health Perspect 1984;55:111-27.

2 Heppleston AG, Styles JA. Activity of a macrophage factor in collagen formation by silica. Nature 1967;214:521-2.

3 Allison AC, Harington JS, Birbeck M. An examination of the cytotoxic effects of silica on macrophages. $J$ Exp Med 1966;124:141-54.

4 Nash T, Allison AC, Harington JS. Physico-chemical properties of silica in relation to its toxicity. Nature 1966;210:259-61.

5 Harington JS, Allison AC, Badami DV. Mineral fibres: chemical, physiocochemical and biological properties. Adv Pharmacol Chemother 1975;12:291-402.

6 Allison AC. Lysosomes and the toxicity of particulate pollutants. Arch Intern Med 1971;128:131-9.

7 Heppleston AG. Silicotic fibrogenesis: a concept of pulmonary fibrosis. Ann Occup Hyg 1982;26:449-62.

8 Gabor S, Anca Z. Effect of silica on lipid peroxidation in the red cells. Internationales Archiv für Arbeitsmedizin 1974;32:327-32.

9 Gabor S, Anca Z, Zugravu E. In vitro action of quartz on alveolar macrophage lipid peroxides. Arch Environ Health 1975;30: 499-501.

10 Kilroe-Smith A. Peroxidative action of quartz in relation to membrane lysis. Environ Res 1974;7:110-6.

11 Chvapil M, Stankova L, Malshet V. Lipid peroxidation as one of the mechanisms of silica fibrogenicity? I. Study with erythrocytes. Environ Res 1976;11:78-88.

12 Zsoldos T, Tigyi A, Montaskó T, Puppi A. Lipid peroxidation in the membrane damaging effect of silica-containing dust on rat lungs. Exp Pathol 1983;23:73-7.

13 Woźniak H, Gościcki J, Więcek E, Spiechowicz E. Changes of some biochemical indices in experimental pneumoconioses. Med Pr 1975;26:123-33. (In Polish.)

14 Wiecek E, Woźniak H, Gościcki J. Standard silica dust used in studies of fibrogenic effect of industrial dusts. Przegl Lek 1981;38:647-50. (In Polish.)

15 Szendzikowski S, Lao I, Kolakowski J. The morphologic and ultrastructural evaluation of biological effect of silicon dust proposed as a standard dust. Przegl Lek 1981;38:651-8. (In Polish.)

16 Zitting A, Skyttä E. Biological activity of titanium dioxides. Int Arch Occup Environ Health 1979;43:93-7.

17 Stegemann H, Stolder K. Determination of hydroxyproline. Clin Chim Acta 1967:18:267-73.

18 Schaub MC. Qualitative and quantitative changes of collagen in parenchymatous organ of the rat during ageing. Gerontologia 1963;8:114-22.

19 Sawant PL, Shibko S, Kumta US, Tappel AL. Isolation of rat-liver lysosomes and their general properties. Biochem Biophys Acta 1964;85:82-92.

20 Lowry OAH, Rosebrough NJ, Farr AL, Randall RJ. Protein measurement with the Folin phenol reagent. $J$ Biol Chem 1951:193:265-75.

21 Nimmo-Smith RH. p-Nitrophenyl $\beta$-glucuronide as a substrate for $\beta$-glucuronidase. Biochem Biophys Acta 1961;50:166-9.

22 Anson ML. Proleolytic enzymes: cathepsin. In: Summer JB, Somers RF, eds. Chemistry and methods of enzymes. New York: Academic Press Inc, 1947:192-3.

23 Mihara M, Uchiyama M, Fukuzawa $K$. Thiobarbituric acid value on fresh homogenate of rat as a parameter of lipid peroxidation in aging, $\mathrm{CCl}_{4}$ intoxication and vitamin $\mathrm{E}$ deficiency. Biochem Med 1980;23:302-11.

24 Wills ED. Mechanism of lipid peroxide formation in animal tissues. Biochem J 1966;99:667-76.

25 Wills ED, Wilkinson AE. Release of enzymes from lysosomes by irradiation and the relation of lipid peroxide formation to enzyme release. Biochem $J$ 1966;99:657-66.

26 Chvapil M, Eskelson DC, Stiffel V, Owen JA. Early changes in the chemical composition of the rat lung after silica administration. Arch Environ Health 1979;34:402-6.

27 Heppleston AG. Cellular reactions with silica. In: Bendz G, Lidquist I, eds. Biochemistry of silicon and related problems. New York and London: Plenum Publishing Corporation, 1978:357-79. (Nobel symposium 40.)

28 Davies $R$. The effect of dust on enzyme release from macrophages. In: Brown RC, Chamberlain M, Davies R, Gormley IP, eds. The in vitro effects of mineral dusts. London: Academic Press. 1980:67-74.

29 Jajte J, Lao I, Wiśniewska-Knypl JM. Enhanced lipid peroxidation and lysosomal enzymes activity in lungs of rats with longlasting pulmonary deposit of crocidolite asbestos. Br J Ind Med 1987:44:180-6.

30 Bienkowski RS. Intracellular degradation of newly synthesized collagen. In: Alan R. Liss, Inc. Intracellular Protein Catabolism 1985:565-72.

31 Werb Z, Bande MJ, Jones PA. Degradation of connective tissue matrices by macrophages. I. Proteolysis of elastin, glycoproteins and collagen by proteinases isolated from macrophages. J Exp Med 1980;152:1340-57. 